\title{
The crystal chemistry of iron (III) monophosphates with mono and divalent metallic cations
}

\author{
A. Badri, M. Hidouri, B. Lajmi and M. Ben Amara \\ Research Unit "Inorganic Materials", Faculty of Science, University of Monastir, Tunisia
}

\begin{abstract}
As a contribution to the study of alkaline iron (III) monophosphates, we recently investigated the $\mathrm{A}_{3} \mathrm{PO}_{4}-\mathrm{M}_{3}\left(\mathrm{PO}_{4}\right)_{2}$ $\mathrm{FePO}_{4}$ (A: alkali metal; M: divalent cation) using both the flux method and the solid state reaction. This investigation led to the synthesis and structural characterization of twelve new compounds. Their structural analysis showed them to be constructed by $\mathrm{PO}_{4}$ tetrahedra and $\mathrm{FeO}_{\mathrm{x}}$ polyhedra $(\mathrm{x}=6,5,4)$. The Fe polyhedra are either isolated or forming finite units of corner- or edge-sharing, or infinite chains of edge-sharing octahedra. The resulting Fe structural units are linked by the $\mathrm{PO}_{4}$ tetrahedra via corner or edge-sharing, giving rise to mixed covalent frameworks which can be either bi- or three-dimentionnel. The alkali cations occupy the interlayer space or tunnels and cavities.
\end{abstract}

\section{INTRODUCTION}

Synthetic alkaline iron monophosphates form a group of compounds exhibiting various chemical compositions and complicated crystal structures. These materials are extensively studied, not only for their interesting applications in catalysis [1] and ionic conductivity [2] but also because of the richness of their structural chemistry. This richness is mainly due to the inductive effect, exerted by pentavalent phosphorus atoms on iron through the common oxygen ions bridging phosphorus and iron. The resulting competition between the $\mathrm{P}-\mathrm{O}$ and $\mathrm{Fe}-\mathrm{O}$ bonds in Fe-O-P chains causes a strong distortion of $\mathrm{Fe}$ environments. Additionally, the Fe polyhedra display several connection fashions to each other and to the phosphate tetrahedra giving rise to a multitude crystal structures.

In this paper, we propose a structural analysis of some new iron (III) monophosphates, synthesized during our investigation of the $\mathrm{A}_{3} \mathrm{PO}_{4}-\mathrm{M}_{3}\left(\mathrm{PO}_{4}\right)_{2}-\mathrm{FePO}_{4}$ systems, (A is an alkali metal and $\mathrm{M}$ is a divalent cation). The reported structures are classified on the basis of three structural criteria: (1) the coordination of iron (III) and the Fe polyhedral units, (2) the connectivity between these units and the $\mathrm{PO}_{4}$ tetrahedra within the Fe-P-O framework, (3) the nature of the anionic frameworks.

\section{EXPERIMENTAL}

The compounds studied here have been synthesized either as single crystals by the flux method or as powders by solid state reaction and their crystal structures have been determined by X-ray diffraction.

\section{RESULTS AND DISCUSSION}

\subsection{The environment of iron atoms}

In the alkali iron (III) phosphates, the $\mathrm{Fe}^{3+}$ ions can adopt different coordination (from 4 to 6 ). The connectivity of the $\mathrm{FeO}_{\mathrm{x}}(\mathrm{x}=4,5,6)$ polyhedra is summarized in Figure 1. This figure shows that one structure can contain more than one type of Fe polyhedra.

In the structures containing only $\mathrm{FeO}_{6}$ octahedra, these polyhedra can be either isolated or forming finite clusters by sharing corners $\left(\mathrm{Fe}_{2} \mathrm{O}_{11}\right)$ or edges $\left(\mathrm{Fe}_{2} \mathrm{O}_{10}\right)$ or infinite chains by sharing edges.

In the structures containing both $\mathrm{FeO}_{6}$ and $\mathrm{FeO}_{5}$ polyhdra, these polyhedra can be either isolated or associated in pairs by corner-sharing to form $\mathrm{Fe}_{2} \mathrm{O}_{10}$ units. In the remaining structures, containing either $\mathrm{FeO}_{5}$ or $\mathrm{FeO}_{4}$, or both $\mathrm{FeO}_{6}$ and $\mathrm{FeO}_{4}$, these polyhedra are isolated from each other.

\subsection{Mixed units in the Fe-P-O frameworks}

The reported alkali iron phosphates were classified on the basis of the connection of the iron polyhedra to the $\mathrm{PO}_{4}$ tetrahedra in the Fe-O-P framework. Several mixed groups are met and are illustrated in Figure 1. They are either finite or infinite, in which the connection of the Fe units to the $\mathrm{PO}_{4}$ tetrahedra is made up via corner- or edge-sharing.

\subsection{Structural classification based on the anionic frameworks}

The structures of the studied compounds are of great diversity but all of them are built up from covalent anionic frameworks, either bi- or three-dimensional. Their comparison showed that they can be classified according to the nature of these frameworks and the emplacement of the alkali cation. Three classes were then distinguished: (1) layered structures, (2) structures with tunnels and (3) structures with cavities.

\subsubsection{Layered structures}

Among the studied compounds, three exhibit layered frameworks: $\quad \mathrm{Na}_{3} \mathrm{Fe}\left(\mathrm{PO}_{4}\right)_{2}, \quad \mathrm{Na}_{3} \mathrm{Fe}_{3}\left(\mathrm{PO}_{4}\right)_{4} \quad$ and $\mathrm{KMgFe}\left(\mathrm{PO}_{4}\right)_{2}$ (figure 2). 


\begin{tabular}{|c|c|}
\hline The Fe polyhedral units [Ref] & $\begin{array}{l}\text { The mixed units } \\
\text { in the Fe-O-P } \\
\text { framework }\end{array}$ \\
\hline \multicolumn{2}{|l|}{$\mathrm{FeO}_{6}$} \\
\hline \multicolumn{2}{|l|}{ Isolated octahedra } \\
\hline $\mathrm{K}_{3} \mathrm{Fe}\left(\mathrm{PO}_{4}\right)_{2}$ & \\
\hline $\mathrm{NaBaFe}_{2}\left(\mathrm{PO}_{4}\right)_{3}$ & \\
\hline $\mathrm{KCuFe}\left(\mathrm{PO}_{4}\right)_{2}$ & \\
\hline \multicolumn{2}{|l|}{$\begin{array}{l}\text { Pairs of octahedra sharing } \\
\text { corners }\end{array}$} \\
\hline \multicolumn{2}{|l|}{$\mathrm{Na}_{3} \mathrm{Fe}_{3}\left(\mathrm{PO}_{4}\right)_{4}$} \\
\hline \multicolumn{2}{|l|}{$\begin{array}{l}\text { Pairs of octahedra sharing } \\
\text { edges }\end{array}$} \\
\hline \\
\hline \multicolumn{2}{|l|}{$\mathrm{Na}_{1 / 2} \mathrm{Cu}_{4 / 3} \mathrm{Fe}_{2}\left(\mathrm{PO}_{4}\right)_{3}$} \\
\hline \multicolumn{2}{|l|}{$\mathrm{Na}_{1,28} \mathrm{Ni}_{0.86} \mathrm{Fe}_{2}\left(\mathrm{PO}_{4}\right)_{3}$} \\
\hline \multicolumn{2}{|l|}{$\begin{array}{l}\text { Chains of edge-sharing } \\
\text { octahedra }\end{array}$} \\
\hline \multicolumn{2}{|l|}{$\mathrm{Na}_{2} \mathrm{Mn}_{2(1-\mathrm{x})} \mathrm{Cd}_{2 \mathrm{x}} \mathrm{Fe}\left(\mathrm{PO}_{4}\right)_{3} \quad$ [10] } \\
\hline \multicolumn{2}{|l|}{$\mathrm{FeO}_{5}$} \\
\hline \multicolumn{2}{|l|}{ Isolated trigonal bipyramids } \\
\hline \multicolumn{2}{|l|}{$\mathrm{K}_{4} \mathrm{MgFe}_{3}\left(\mathrm{PO}_{4}\right)_{5}$} \\
\hline \multicolumn{2}{|l|}{$\mathrm{FeO}_{4}$} \\
\hline \multicolumn{2}{|l|}{ Isolated tetrahedra } \\
\hline \multicolumn{2}{|l|}{$\mathrm{KMgFe}\left(\mathrm{PO}_{4}\right)_{2}$} \\
\hline \multicolumn{2}{|c|}{$\mathrm{FeO}_{6}$ and $\mathrm{FeO}_{5}$} \\
\hline $\begin{array}{l}\text { Isolated } \mathrm{FeO}_{5} \text { and } \mathrm{FeO}_{6} \\
\text { polyhedra }\end{array}$ & \\
\hline $\mathrm{NaCaFe}_{3}\left(\mathrm{PO}_{4}\right)_{4}$ & \\
\hline \multicolumn{2}{|l|}{ Corner-sharing polyhedra } \\
\hline \multicolumn{2}{|l|}{$\mathrm{Rb}_{9} \mathrm{Fe}_{7}\left(\mathrm{PO}_{4}\right)_{10}$} \\
\hline \multicolumn{2}{|c|}{$\mathrm{FeO}_{6}+\mathrm{FeO}_{4}$} \\
\hline $\begin{array}{l}\text { Isolated } \mathrm{FeO}_{4} \text { and } \mathrm{FeO}_{6} \\
\text { polyhedra }\end{array}$ & \\
\hline $\mathrm{NaZnFe}_{2}\left(\mathrm{PO}_{4}\right)_{3}$ & \\
\hline
\end{tabular}

Figure 1. The connectivity between the Fe polyhedra and the $\mathrm{PO}_{4}$ tetrahedra.

In $\mathrm{Na}_{3} \mathrm{Fe}\left(\mathrm{PO}_{4}\right)_{2}$ and $\mathrm{KMgFe}\left(\mathrm{PO}_{4}\right)_{2}$, the layers are built up from corner-sharing $\mathrm{FeO}_{\mathrm{x}}$ and $\mathrm{PO}_{4}$ polyhedra whereas in $\mathrm{Na}_{3} \mathrm{Fe}_{3}\left(\mathrm{PO}_{4}\right)_{4}$, they are constructed by $\mathrm{FeO}_{6}$ octahedra which are linked both directly by sharing corners and by means of the $\mathrm{PO}_{4}$ tehtrahedra through

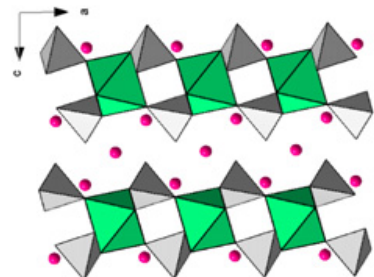

(a)

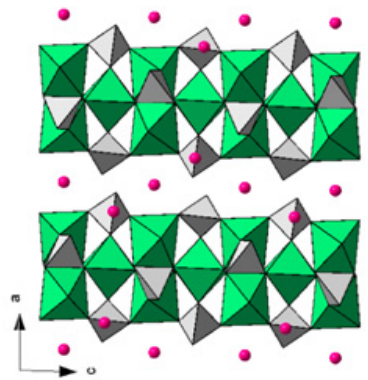

(b)

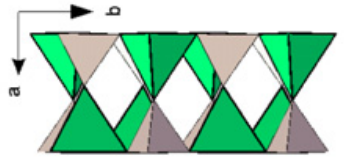

$\bullet \bullet \bullet$

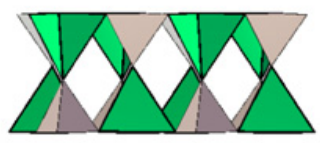

(c)

Figure 2. Layered structures: (a) $\mathrm{Na}_{3} \mathrm{Fe}\left(\mathrm{PO}_{4}\right)_{2}$, (b) $\mathrm{Na}_{3} \mathrm{Fe}_{3}\left(\mathrm{PO}_{4}\right)_{4}$ and (c) $\mathrm{KMgFe}\left(\mathrm{PO}_{4}\right)_{2}$.

common corners. The comparison of these structures with that of layered $\mathrm{LiFePO}_{4}$ revealed the existence of some correlation between the mean $<\mathrm{Fe}-\mathrm{O}\rangle$ distance within the $\mathrm{Fe}$ polyhedra and the nature of the $\mathrm{A}^{+}$cation occupying the inter-layer space. Indeed, when going from $\mathrm{Li}^{+}$to $\mathrm{Na}^{+}$ and $\mathrm{K}^{+}$, the average distance $<\mathrm{Fe}-\mathrm{O}>$ decreases from $2.16 \AA$ in $\mathrm{LiFePO}_{4}$ [16] to the vicinity of $2.02 \AA$ in $\mathrm{Na}_{3} \mathrm{Fe}\left(\mathrm{PO}_{4}\right)_{2}$ and $\mathrm{Na}_{3} \mathrm{Fe}_{3}\left(\mathrm{PO}_{4}\right)_{4}$ and then to $1.88 \AA$ in $\mathrm{KMgFe}\left(\mathrm{PO}_{4}\right)_{2}$. This decrease would explain the inexistence of lithium and $\mathrm{Fe}$ (III) phosphates with layered structures.

\subsubsection{Structures with tunnels}

This class encloses a variety of structures among which the alluaudite is the most widespread. This structure covers a wide range of compositions attesting its high susceptibility for cation substitutions. Indeed, the alluaudite is a family of phosphates mostly natural and whose compositions can be summarized as $(\mathrm{Na}, \square)(\mathrm{Na}, \mathrm{Ca})\left(\mathrm{Mn}^{2+}\right)\left(\mathrm{Fe}^{2+}, \mathrm{Fe}^{3+}\right)_{2}\left(\mathrm{PO}_{4}\right)_{3}$ where $\square$ is a vacancy. Its structure has been described by Moore who proposed the general formula $\mathrm{X}(2) \mathrm{X}(1) \mathrm{M}(1) \mathrm{M}(2)_{2}\left(\mathrm{PO}_{4}\right)_{3}$ where $\mathrm{X}(2), \mathrm{X}(1), \mathrm{M}(1)$ and $\mathrm{M}(2)$ are cationic sites 


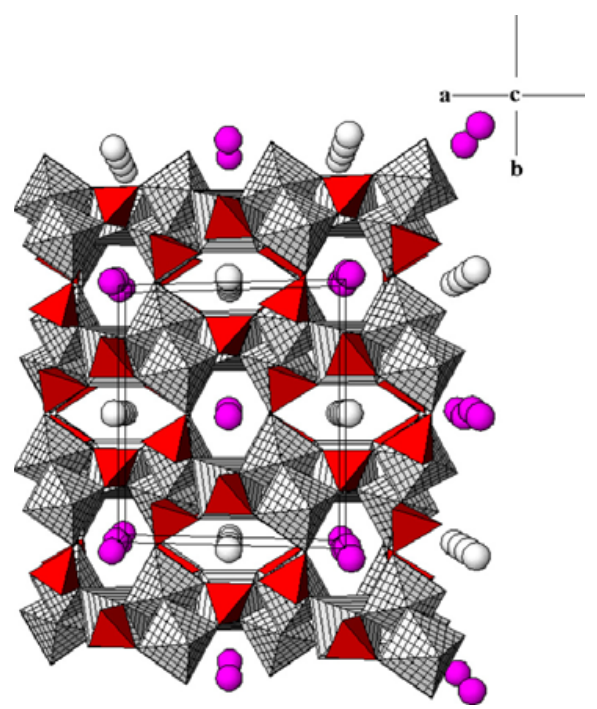

Figure 3. Structure with tunnels: the Alluaudite type structure.

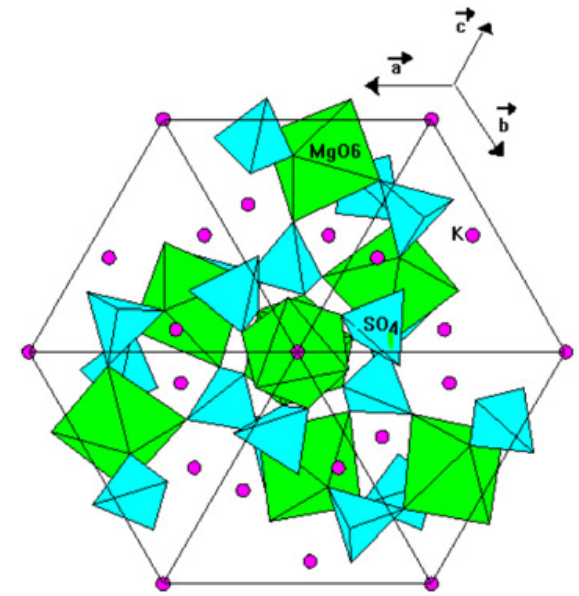

Figure 4. The langbeinite structure $\mathrm{K}_{2} \mathrm{Mg}_{2}\left(\mathrm{SO}_{4}\right)_{3}$.

ranked in decreasing order of their sizes [17]. The $\mathrm{M}(1) \mathrm{O}_{6}$ and $\mathrm{M}(2) \mathrm{O}_{6}$ octahedra share edges to form infinite chains $[-\mathrm{M}(2)-\mathrm{M}(2)-\mathrm{M}(1)-]_{\infty}$ running parallel to the $\left[\begin{array}{lll}1 & 0 & -1\end{array}\right]$ direction. The connection of these chains is ensured by $\mathrm{PO}_{4}$ tetrahedra. The resulting threedimensional framework forms two types of tunnels parallel to the $\left[\begin{array}{lll}0 & 0 & 1\end{array}\right]$ direction and containing $X(2)$ and $X(1)$ sites (Figure 3). More recently, Hatert and his collaborators demonstrated that $\mathrm{X}(2)$ sites are spitted in two positions labeled $\mathrm{A}(2)$ and $\mathrm{A}(2)^{\prime}$ and $\mathrm{X}(1)$ in three positions labeled $\mathrm{A}(1), \mathrm{A}(1)^{\prime}$ and $\mathrm{A}(1)^{\prime \prime}$. The alluaudite general formula was then reformulated as: $\left[\mathrm{A}(2), \mathrm{A}(2)^{\prime}\right][\mathrm{A}(1)$, $\left.\mathrm{A}(1)^{\prime}, \mathrm{A}(1)^{\prime \prime}\right] \mathrm{M}(1) \mathrm{M}(2)_{2}\left(\mathrm{PO}_{4}\right)_{3}[18]$.

In the course of this work, we studied the influence of the nature and size of the $\mathrm{A}$ and $\mathrm{M}$ cations on the stability of the alluaudite. The obtained results together with the literature data allowed us to conclude that based on geometrical considerations, the site occupancy is closely related to the size of the involved cations. In fact, potassium which generally adopts 8 coordination, can only occupy the site $\mathrm{A}(2)^{\prime}$. Sodium whose coordination vary from 8 to 6 , preferentially occupies the site $\mathrm{A}(1)$ then the $\mathrm{A}(2)^{\prime}$ site. Lithium whose coordination oscillates
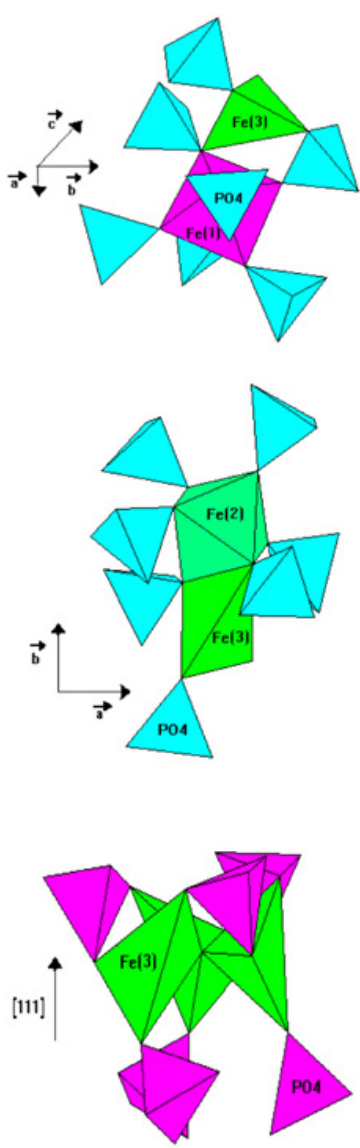

Figure 5. Environments of iron polyhedra in $\mathrm{K}_{11} \mathrm{Fe}_{15}\left(\mathrm{PO}_{4}\right)_{18} \mathrm{O}$.

between 4 and 6 statistically occupies the $\mathrm{A}(1)^{\prime}$ and $A(1)^{\prime \prime}$ sites. These sites cannot be occupied simultaneously because of the short distance between them. Site A(1)" can accommodate manganese with 5 or 6 coordination. In addition, the $\mathrm{M}(1)$ site preferentially accepts divalent elements such as $\mathrm{Mg}, \mathrm{Ca}, \mathrm{Mn}, \mathrm{Cd}$, but sometimes it can receive small amounts of $\mathrm{Fe}(\mathrm{III})$ or Na. The $\mathrm{M}(2)$ site is preferentially reserved to $\mathrm{Fe}(\mathrm{III})$ but can also accommodate small amounts of divalent elements.

\subsubsection{Structures with cavities}

Three structures forming cavities have been met: $\mathrm{NaZnFe}_{2}\left(\mathrm{PO}_{4}\right)_{3}, \mathrm{NaCaFe}_{3}\left(\mathrm{PO}_{4}\right)_{4}$ and $\mathrm{NaBaFe}_{2}\left(\mathrm{PO}_{4}\right)_{3}$. In the first, the cavities contain only the sodium ions. By contrast, in the two others, they contain disordered distributions of sodium and the divalent cation. The zinc and calcium phosphates have original structures however the barium one exhibits the well known langbeinite type. This structure covers a wide range of compositions attesting its high capacity for cation substitutions. The prototype is a the magnesium and potassium sulphate $\mathrm{K}_{2} \mathrm{Mg}_{2}\left(\mathrm{SO}_{4}\right)_{3}$. It crystallizes in the cubic system with space group $\mathrm{P} 2{ }_{1} 3$ [19]. Its structure (Figure 4) is built up on the basis of octahedra $\mathrm{MgO}_{6}$ corner sharing with the $\mathrm{SO}_{4}$ tetrahedra.

In the case of iron phosphate, langbeinite structure can be stabilized if the iron ions substitute the magnesium 
ones and the $\mathrm{PO}_{4}$ groups replace the $\mathrm{SO}_{4}$ ones. This was possible in the following cases:

1. The substitution of $\mathrm{Ba}^{2+}$ to $\mathrm{K}^{+}$leading to $\mathrm{KBaFe}_{2}\left(\mathrm{PO}_{4}\right)_{3}$ widely studied for its magnetic properties [20]. The replacement in this compound of potassium by sodium does not affect the stability of this structure since it leads to the langbeinite-like phosphate $\mathrm{NaBaFe}_{2}\left(\mathrm{PO}_{4}\right)_{3}$ [4].

2. The replacement of $\mathrm{MoO}_{4}^{2-}$ or $\mathrm{SO}_{4}^{2-}$ to $\mathrm{PO}_{4}^{3-}$ leading to the mixed compounds $\mathrm{K}_{2} \mathrm{Fe}_{2}\left(\mathrm{MoO}_{4}\right)\left(\mathrm{PO}_{4}\right)_{2}$ and $\mathrm{K}_{2} \mathrm{Fe}_{2}\left(\mathrm{SO}_{4}\right)\left(\mathrm{PO}_{4}\right)_{2}$ [21], in which the anionic groups are distributed statistically.

3. According to the general formula $\mathrm{K}_{2-\mathrm{x}} \mathrm{Fe}_{2+3 \mathrm{x}}$ $\left(\mathrm{PO}_{4}\right)_{3} \mathrm{O}_{\mathrm{x}}$, the $\mathrm{x}=1 / 6$ composition leads the oxyphosphate $\mathrm{K}_{11} \mathrm{Fe}_{15}\left(\mathrm{PO}_{4}\right){ }_{18} \mathrm{O}$ [22] in which the additional iron is set in a interstitial site with a coordination number between 4 and 5 (Figure 5).

\section{CONCLUSION}

In the alkali iron monophosphates, the ability of iron to adopt various oxygen environments and the variety of modes of its association to the $\mathrm{PO}_{4}$ tetrahedra leads to a huge anionic Fe-P-O frameworks. In these frameworks, the Fe polyhedra can be either isolated from each other or linked via corner or edge-sharing to form finite clusters or infinite chains. Such Fe units are linked to the phosphate groups by sharing corners or edges and the resulting frameworks can be either lamellar in which the alkali cations occupy the interlayer space or three-dimensional, delimiting tunnels or cavities where the alkali cations are located.

\section{References}

[1] H. Y. Hong, Mat. Res. Bull. 11, 173 (1976).

[2] J. B. Moffat, Catal., Rev. Sci. En. 18, 199 (1978).

[3] B. Lajmi, M. Hidouri, A. Ben Hammouda, A. Wattiaux, L. Fournés, J. Darriet, M. Ben Amara, Mater. Chem. Physics 113, 372 (2009).
[4] M. Hidouri, H. Jerbi, M. Ben Amara, Acta Cryst. E64, i5 (2008).

[5] A. Badri, M. Hidouri, M. L. López, C. Pico, A. Wattiaux, M. Ben Amara, J. Solid State Chem. 184, 937 (2011).

[6] B. Lajmi, M. Hidouri, M. Rzeigui, M. Ben Amara, Mater. Res. Bull. 37, 2407 (2002).

[7] M. Hidouri, B. Lajmi, A. Wattiaux, L. Fournés, J. Darriet, M. B. Amara., J. Solid State Chem. 177, 55 (2004).

[8] M. Hidouri, B. Lajmi, A. Wattiaux, L. Fournés, J. Darriet, M. B. Amara., J. Solid State Chem. 179, 1808 (2004).

[9] M. Hidouri, B. Lajmi, A. Driss, M. B. Amara., J. Chem. Crstallogr. 34, 669 (2004).

[10] M. Hidouri, B. Lajmi, A. Wattiaux, L. Fournés, J. Darriet, M. B. Amara., C. R. Chimie 14-10, 904 (2011).

[11] M. Hidouri, N. Sendi, A. Wattiaux, M. B. Amara, J. Phys. Chem. Solids 69, 10 (2008).

[12] A. Badri, M. Hidouri, M. L. López, M. L. Veiga, A. Wattiaux, M. B. Amara, Solid State Ionics 180, 1558 (2009).

[13] M. Hidouri, B. Lajmi, A. Wattiaux, L. Fournés, A. Wattiaux, J. Darriet, M. Ben Amara, J. Alloys Comp. 358, 36 (2003).

[14] M. Hidouri, A. Wattiaux, M. L. López, C. Pico, M. Ben Amara, J. All. Comp. 506, 569 (2010).

[15] M. Hidouri, B. Lajmi, M. Ben Amara, Acta Cryst. C58, i147 (2002).

[16] V.A. Streltsov, E.L. Belokoneva and al., Acta Cryst., B 49, 147 (1993).

[17] P. B. Moore, Am. Mineral. 56, 1955 (1971).

[18] F. Hatert, P. Keller, F. Lissner, D. Antenucci, A. M. Fransolet, Eur. J. Mineral 12, 847 (2000).

[19] K. Mareiter, Neues Jb. Miner., Mh., 182 (1979).

[20] P. D. Battle, A. K. Cheetham, W. T. A. Harrison, G. J. Long, J. Solid State Chem. 62, 16 (1986).

[21] B. Lajmi, PhD Thesis, Faculty of Sciences of Monastir (2005).

[22] B. Lajmi, M. Hidouri, A. Wattiaux, L. Fournés, J. Darriet, M. Ben Amara, J. Alloys Comp. 361, 77 (2003). 